\title{
Understanding Prudence Corporate Governance: An Alternative Approach
}

\author{
Zakaria Abas ${ }^{1, *}$ \\ ${ }^{1}$ UUM, College Of Business, 06010 Sintok Kedah, Malaysia
}

\begin{abstract}
In the past decades, the world was stunned by the collapse of few established corporate organization worldwide. These high profile organizations are said to have a weak corporate governance system among others lack of accountability, lack of transparency and poor leadership and decision making that plunge their organization towards an endemic financial and management crisis. Since then and until today, corporate governance received a continuous high attention by all parties concerned, whereby exercising good corporate governance practises is becoming a mandatory within their respective organization. To elaborate further, perhaps maybe there is an abundance of established guidelines and practical perspective of corporate governance within the literature, however, this paper offers an attention-grabbing alternative approach of understanding prudent corporate governance thought that based on Islamic perspective. Perhaps we could revisit the philosophy of corporate governance, review the possibilities in light of adopting a more comprehensive perspective on the concept of development which includes individual, organizational and societal goals.
\end{abstract}

Keywords: Corporate governance, Islamic corporate governance

\section{Introduction}

Over the past few decades, much has been discussed on the endemic financial crisis shrouding East Asia with particular focus on the structural weaknesses in the affected countries. Malaysia is no exception. Among these is the governance of the corporate sector. Our economic crisis has shown us how the lack of corporate governance has exacted a heavy toll on the market and as a result depleted investors' confidence. Although there are contending, varied and complex views on the causes of the crisis, many were acquiescent that weak corporate governance was partly to be blamed for poor investment decisions, lower quality public investment and public services, reduced private investment, risky financing practices and the resultant large-scale non-performing loans in the financial sector, growing number of corporate bankruptcies, and poor audits.

\footnotetext{
*Corresponding author: zakaria@uum.edu.my
} 
Nevertheless, the crisis was somewhat a blessing in disguise, for the excesses of the past and deluge of corporate collapses seem to have led to increasing awareness and emphasis on the issues of corporate governance. Overnight, the term has become a corporate buzzword. Just what is corporate governance? To put it simply, it means that corporations must exercise greater accountability when undertaking their business operations, both to their shareholders and the public at large. It is in fact a systematic framework that provides a blueprint for the companies to manage themselves in the best interest of the shareholders and to manage risks in an increasingly competitive global economy.

Given the background in the preceding paragraphs, this paper promotes a brief and preliminary thought on the basic issues relating to: i) enhanced role of the company directors, ii) whether corporate governance is value-loaded, iii) central element of corporate governance, iv) the dual nature of man, v) the concepts and philosophy of corporate management in Islam, vi) social responsibility and managerial accountability, vii) success and failures in managing business, leadership and decision making process. Finally, this paper provides a conclusion on the related issues relating the alternative approach to corporate governance.

\section{Enhanced Roles of the Company Directors}

Enhancing corporate governance involves a collective responsibility among regulatory agencies, professional bodies, corporate leaders as well as investors and stakeholders. There is now a greater demand for transparency and accountability from corporate leaders such as company directors. Directors are expected to achieve high performances for their companies while acting in accordance with the prevailing regulatory requirements. A vital element of corporate governance seems to lie with the board of directors and the way management is run, with a sense of stewardship, responsibility and accountability to shareholders, who are the legal owners of corporations. The board of directors is entrusted with the conduct and daily management of business activities and commercial feasibility of the venture by using the assets made available. Directors are, therefore, subjected to higher standards which cover not only the technical efficiency of operations, but also the implementation of an efficient management system through the use of best practices developed from high ethical values.

Moral and ethical values have been much discussed but less seen practiced among the corporate leaders. Company directors are in fact leaders that play a significant role in shaping the colour of their corporations. We have learned from the past that a successful leader is one who builds core values in people he leads. This requires him to have a sound moral education, imbibed with spiritual values, which when combined with leadership, training and delegation, will result in his people being able to clearly and unhesitatingly differentiate between right and wrong, moral and immoral, ethical and unethical practices in their pursuit of achieving success.

\section{Is Corporate Governance Value-Loaded?}

The aim of this paper is to address the issue of "how do we move towards an alternative approach of corporate governance, say, Islamic Corporate Governance?" Is there any such term as Islamic and non-Islamic corporate governance, that is, is corporate governance value-loaded? Let us revisit at the definition of corporate governance as spelled out by the [3],"Corporate governance is the process and structure used to direct and manage the business and affairs of the company towards enhancing business prosperity and corporate 
accountability with the ultimate objective of realizing long-term shareholder value, whilst taking into account the interests of other stakeholders".

Clearly, there arise a few issues that need to be addressed; firstly, on the concept of business prosperity and corporate accountability; secondly, on the ultimate objective of corporate management; and thirdly, on the legal structures and administrative process in the decision-making by the company's directors. The Finance Committee in their 275-page reports enveloping 70 recommendations has elaborated each of these. As [4] mentioned, [7] wrote in Corporate Governance (1992) that a good governance system should consist of a system of structure, operating and controlling a company to achieve the objectives of fulfilling long-term strategic goals, building shareholders' value by establishing a dominant market share, or be a leader in a chosen sphere; Consideration and care for the needs of the environment and local community, including the economic and cultural interaction; Maintaining excellent relationship with customers and suppliers in terms of quality of service provided, considerate ordering and account settlement procedures; and Maintaining compliance with all legal and regulatory requirements under which the company operates. In broad sense, an effective corporate governance system should provide a mechanism to regulate duties and responsibilities of directors to restrain them from abuse of powers, ensuring they act in the best interest of the company and to be aware of the impact of the company on the business community and the environment. [2] explains succinctly that if management is about running business, governance is about seeing that it runs properly. He elaborated that governance is concerned with the supervision and control of executive actions, the concern for the effect of the entity on other parties; the acceptance of a duty to be accountable; and the regulation of corporation within a jurisdiction of the state in which it operates.

A careful observation of the description above would easily reveal that the central element of corporate governance is primarily and essentially man, be he the director, the manager, the shareholder, the auditor, the stakeholder, or even the regulator. It is man that is involved in the process of managing the business of the company towards achieving its mainstream goal of maximizing the wealth of its owners (the shareholders). The codes of upholding trust, maintaining integrity, exercising transparency and accountability, prudent management of resources, maximizing returns, caring and concern of the environment are but would remain as mere noble codes if the issues of man, his values, ethics and moral conduct are not tackled in the first instance. In short, corporate governance is basically the moral and ethical dimension of managing a company's business. In this regard, corporate governance is indeed very much value-loaded. Man is essentially an ethical and moral being. For the Muslims, the ethical codes of conduct based on the Tawhidiq worldview and Quranic values are considered more elevating than those, which are detached from religious moorings.

\section{The Dual Nature of Man}

Islam looks at man as having a dual nature [5], "one is the animal aspect and the other the spiritual aspect, which is sometimes called rational aspect. When is implied and demanded is that this animal aspect of man be subjugated by the rational one and such submission of the former to the latter affirm and reaffirm its covenant with God". Although Islam enjoins the exercise of rationality but such consumption of man's intellectual capacity has its own limits and defined boundary confined by Divine values. The concept of rationality is not confined to the concept of reason towards the understanding of objects in space and time with their relations and events. The early Muslims have always defined this intellect (Aql) as a spiritual substance. Thus, by rational we also mean to include within such context in which rational operates, not only the world of objects but also that of spiritual and truth. 
In short, Islam calls for balance equilibrium, harmonizing his rational and spiritual dimensions, integrating values and knowledge and placing things in their appropriate position. The sources of guidance for the Muslims are basically the Quran and the Sunnah, the traditions of the Prophet Muhammad (pbuh). To be a Muslim is to submit and worship Allah but it is important to note that the act of submitting and worshipping in Islam does not, again, confine itself adherence of the rules for religious rituals but instead encompasses the code of rules on all the aforementioned activities. This draws demarcation line between Islam and all other religions of the world and this also underlies the key to comprehend the place and significance of Islamic values in all spheres of human value activities, corporate governance inclusive, within the framework of the Islamic value system. These values are part and parcel of the religion itself and the performances in adherence to them is regarded as the act of ibadah - worshipping and submitting - to Allah, just as the performance of prayer and fasting are [1].

In light of the above, and of Quranic revelations concerning the reality of God, man and the universe, the scope and meaning of corporate governance as far as Muslim managers are concerned assume a broader and more comprehensive import that what is normally conceived by conventional and contemporary schools of thought.

\section{The Concept and Philosophy of Corporate Governance in Islam}

The philosophy of corporate governance in Islam resides upon three distinct aspects, namely, values, knowledge (intellectual) and competency. The fundamental of all values rested upon the concept of vicegerency (khalifah) or trusteeship. The underlying message in this concept is: man's position in relation to man (enjoining good deeds and forbidding evil doings); secondly, man's position in relation to nature (to work, develop and exploit the natural resources of the earth in accordance with the ordained principles); thirdly and most importantly, man's position in relation to his Creator, Allah. In essence, its chief objective inherent in its philosophy of managing a business is, to organize human society and its main systems and disciplines on the basis of social justice for all, irrespective of color, creed or race and to establish concepts of goodness, virtue and benevolence among people so that they are able to enjoy life of security, peace, prosperity and happiness on an individual as well as at social level.

The concept of managing life, governing a corporation, leading a community or society, rests upon the cardinal principle of submission to Allah. This notion has a deep and broad implications to Muslims for the acceptance of Allah as their Lord implies a binding covenant and what follows is the submission to the rules, desires and the will of their Lord, hence the religion Islam which means submission.

\section{Social Responsibilities and Managerial Accountability}

Islam looks at accountability and responsibility in a different light. In terms of responsibility, the manager is not merely responsible to his human superiors; he, as a servant and trustee of Allah in all situation, is simultaneously responsible to Allah, the Owner of his very self and the resources he is utilizing and managing. This responsibility to Allah, is in fact a function to the intrinsic quality of the manager's life as an Amanah (trust) from Allah. To forget or to neglect this fundamental aspect of managerial responsibility tantamount to a betrayal (khianat) of the Divine trust, and will result with all the attending consequences in this world and in the next. Here again, we see that the concept of 
accountability in professional literature and culture is confined only to public accountability or accountability to human superiors. The Islamic concept of accountability extends the scope of human answerability to God as the Judge and Ruler of man, and not merely as a Creator. The concept of Taqwa (mindfulness of the pleasure and displeasure of God for all human actions) has to be understood in the context of the activities of the professional and corporation.

The make up a more wholesome meaning of human existence is defensible. In tandem with this aspiration, the concept of work and dedication to work as a form of ibadah (worship in its wider sense) and 'amal soleh' (virtuous act) together with religious observances are warranted. The concept of Allah as the Real Manager of resources helps to liberate the human mind from the false sense of autonomy and dominion over the resources.

\section{Success and Failures in Managing Business}

It is without doubt that the ultimate objective of directing and managing the business and affairs of the company is that of enhancing shareholder value. Ultimately, the owners of the business, the shareholders - expect to receive an appropriate return on their investment. Generally, the success and failure of a business organization is usually viewed in terms of profit and loss. Although the objectives of getting higher monetary and material returns are not in themselves objectionable in Islam, provided the means employed are lawful and the gains legitimate, the idea of success being limited solely to materialistic and temporal consideration are alien to the Islamic worldview.

Islamic managers who are imbued with the worldview of Tawhid (ones of God) are not anti-profit or anti-worldly gain within the limits provided by religion. Their vision of success and failure extend beyond worldly existence to the life in the hereafter. In the Quranic definition of success (al-falah), a true gain is a gain that persists to the life eternal and a true loss (khusran) is a loss that is also experienced in the hereafter. Since in the Islamic vision of reality, human life does not begin and end here, but continues unbroken beyond the world of phenomenon, and that life in the hereafter is an abiding eternal life of reward and punishment, it follows that the criteria of success and failure cannot be limited to the here and now, but should be equally applicable to the abiding and eternal life. The safest criterion of success, therefore, must entail the question of Divine pleasure and displeasure. Thus, a gain in any form, however, great it may be, which does not lead to felicity and salvation in the hereafter, is not regarded as true success.

Islamic manager's criteria of success and failure either for themselves or for the organizations are derived from the comprehensive concept of al-falah and khusran. This involves the question of the propriety of ends and means. Both ends and means must be legitimate and justifiable from ethical principles of the Quran. The application of this concept of success implies a more holistic planning, goal setting, and implementation of the plans which keep in mind the omniscience and omnipresence of Allah in His universe. The end result of such a holistic vision and endeavor is greater security for everyone, minimum disruption of societal peace and negligible harm to the environment which has been ravaged by the misuse of technology, human callousness, myopia, greed, rivalry for domination and devastative competition - in short, the consequences of man acting as though he is the Master of universe. However, this holistic vision of success and failures does not in any way impair technical efficiency and managerial excellence. 


\section{Leadership and Decision Making Process}

Much has been said about the concept of vicegerency or trusteeship. In essence, the qualities of an Islamic manager (leader) are the qualities of an Islamic man itself [6]. The Holy Prophet Muhammad (pbuh) once said: "Every one of you is a keeper or a shepherd and will be questioned about the well-being of his fold. So, the Head of the State will be questioned about the well-being of the people of the State. Every man is a shepherd to his family and will be answerable about every member of it. Every woman is a shepherd to the family of her husband and will be accountable for every member of it. And every servant (employee) is a shepherd to his master (employer) and will be questioned about the property of his master".

Islam lays down the followings as among the main attributes that must exist in an Islamic manager or administrator (leader), among others; moderate and consistence in his directions and commandments; exercise process of consultation (shura) in decision making; set himself as an exemplary; humble and helpful; honest, uphold justice, committed and responsible in handling subordinates; strive hard to achieve group's objective; and of prime importance, having strong faith in deciding any action.

\section{Conclusions}

The paper attempts to propose an alternative approach of corporate governance by specifically discuss on the issues of corporate governance seen from the Islamic perspective. In as much as corporate governance involves the exercise of greater accountability, enhancing transparency, timely disclosure of information, prudent decision making, good management of resources, and employment of the right code of conduct among the company directors and managers, there is nothing that separates these elements from the Islamic moral codes. The boundary that delineates Islamic approach towards corporate governance and its counterpart rests upon the spiritual and philosophical values of the former. Indeed, corporate governance is basically the moral and ethical dimensions of managing business and at the centre of man with its intractable moral and ethical problems plaguing society, which needs to be addressed. While the Muslims may regard the Tawhidiq worldview and Quranic values as more appropriate in justifying the relevance of employing spiritual-based corporate governance, more often than not, most of these moral codes of conduct are in fact universal in values. Hence, one should not be apologetic for its inability of integrating religious faith and values at the workplace, even within a nonMuslim corporation. In fact, this Divine guidance should be seen as morale enhancement, with the Divine commandments as its complementary compelling force.

Nevertheless, corporate governance is but a small slice of the large ethical code of corporate practice. The intention of institutionalizing it is to enhance public and investors' confidence in the market-place. Indeed, the country has enough codes of ethics to cover all the professions but their enforcement and effectiveness leave much to be desired. If laws, by-laws, statutory regulations, general orders and code of ethics are not effective enough to curb unethical conduct, perhaps we need to review and adopt a more comprehensive perspective on the concept of development which includes individual, organizational and societal goals. Rather than striving to develop Malaysia into a mere industrialized nation, robbed of its soul, perhaps we could aim at achieving it as an exemplary developed moralnation of the East.

The authors would like to thank the anonymous reviewers. 


\section{References}

1. A. Khurshid, Islamic Foundation. Its basic Principles and Characteristics. (1975)

2. B. Tricker, An International Review. Corporate Governance-the subject whose time has come. Corporate Governance: 8(4), 289-296 (2000)

3. F. Committee, Report on Corporate Governance. Corporate Governance. (1999)

4. F.S. Cheah, C. Yeap, MAICSA. Perspectives on Corporate Governance and Management. (1999)

5. $\quad$ S.N. Al-Attas, Berita Publishing: Faces of Islam. (1989)

6. S.O Al-Habshi, INMIND. Islamic Management for Excellence. (1998)

7. T. Sheridan, N. Kendall, Pitman Pub. Corporate governance: An action plan for profitability and business success. (1992) 